DOI 10.22460/infinity.v6i2.p137-148

\title{
ANALYSIS OF MATHEMATIC REPRESENTATION ABILITY OF JUNIOR HIGH SCHOOL STUDENTS IN THE IMPLEMENTATION OF GUIDED INQUIRY LEARNING
}

\author{
Yumiati $^{1}$, Mery Noviyanti ${ }^{2}$ \\ 1,2 Open Universitas, Jl. Cabe Raya Ciputat, Tangerang 15418, Indonesia \\ ${ }^{1}$ yumi@ecampus.ut.ac.id, ${ }^{2}$ merrynov@gmail.com
}

Received: June 13, 2017 ; Accepted: June 19, 2017

\begin{abstract}
The purpose of this research is to analyze the difference in the improvement of students' mathematic representation ability by guided inquiry learning and conventional learning. The subject of the research was eight grade students of UT Dharma Karya Junior High School. There were 19 students chosen as controlling class and 20 students as experiment class. This research used quasi-experimental methods with non-equivalent control group design in one school. Before and after the learning, both of the classes were given mathematic representation. The result of the research showed that the mathematic representation ability of experimental group students with guided inquiry experienced an increase of 0.41 ; it was included in medium category. Meanwhile, students' representation ability of conventional learning group was increased 0,26 and it was included in low category. The results of this study indicated that the mathematical representation ability of the guided inquiry learning group students was significantly better than the students of the conventional learning group.
\end{abstract}

Keywords: Guided Inquiry Learning, Mathematic Representation Ability.

\begin{abstract}
Abstrak
Tujuan penelitian ini adalah untuk menganalisis perbedaan peningkatan kemampuan representasi matematis siswa dengan pembelajaran inkuiri terbimbing dan siswa dengan pembelajaran konvensional. Subjek penelitian adalah siswa SMP Dharma Karya UT kelas 8. Terpilih 19 orang sebagai kelas control dan 20 orang sebagai kelas eksperimen. Penelitian ini menggunakan metode eksperimen semu dengan nonequivalent control group design di satu sekolah. Sebelum dan sesudah pembelajaran, kedua kelas diberikan tes representasi matematis. Hasil penelitian menunjukan bahwa kemampuan representasi matematis siswa kelompok eksperimen dengan pembelajaran inkuiri terbimbing mengalami peningkatan sebesar 0.41, termasuk kategori sedang. Sementara itu, kemampuan representasi siswa kelompok pembelajaran kontrol (konvensional) mengalami peningkatan sebesar 0,26 dan termasuk kategori rendah. Hasil penelitian tersebut menunjukkan bahwa kemampuan representasi matematis siswa kelompok pembelajaran inkuiri terbimbing lebih baik secara signifikan dari siswa kelompok pembelajaran konvensional.
\end{abstract}

Kata Kunci: Kemampuan Representasi Matematis, Pembelajaran Inkuiri Terbimbing.

How to Cite: Yumiati \& Noviyanti, M. (2017). Analysis of Mathematic Representation Ability of Junior High School Students in the Implementation of Guided Inquiry Learning. Infinity, 6 (2), 137-148. doi:10.22460/infinity.v6i2.p137-148 


\section{INTRODUCTION}

Math equipped students to deal with world challenge, which was more growing, and as one tool used was reasoning. This matter was suitable with the statement of Ayalon \& Even (2010), namely math served students a group of unique powerful tool to comprehend and to change the world. These tools scoped logically reasoning, problem solving ability and abstract thinking ability.

In relating with math representation ability of students, it was found that math representation ability of students still had problem, particularly in translating from graphic to verbal and from table to verbal, as expressed by Anastasiadou (2008). Ozyildirim, Ipek \& Akkus (2009) stated that the easiest translation, apparently, it was translation from diagram's representation to algebra, meanwhile the most difficult translation was from table representation to algebra. The problem found relating with student representation ability for example as follow. When students were questioned: "s and $t$ were two numbers and $s$ was eight more than $t$. Wrote down the equation indicated a relation between $s$ and $t$ ". Most student answered " $s+8=t$ ". It showed that students still had a weakness to change from verbal to algebra representation.

In order to upgrade student representation ability, it was necessary to done math learning which gave student opportunity for reasoning and solving problem independently. According to Suryadi (2005), math learning was more emphasizing on reasoning and problem-solving aspects, which enable to produce high performance students on math test, conducted by TIMSS, like in Japan and Korean.

Learning qualified above characters was inquiry learning. Gulo (Trianto, 2009), stated that inquiry strategy meant that a sequence of study activities which involved entire students ability maximally to seek and to inquiry systematically, critically, logically and analytically, so that they could formulate their own invention by fully confidence. Hereby, student math representation ability would be trained. Suitable inquiry learning to junior high school student still needed a study with dominantly teacher guidance was guided inquiry learning.

Based on the above outline, then problem occurred within this research as follow "Was student who gained the guided inquiry learning, obtained the higher upgrade of math representation ability compared than student obtained conventional learning?"

\section{Math Representation Ability (MRA)}

Goldin \& Shteingold (2001) divided the representation into two systems, external and internal representation system. External representation is a kind of signs or symbols, characters, or object to symbolize, depict, encode, or represent something other than itself. External representations can be: 1) notation and formal, such as the number system, algebraic notation, equations, function notation, derivative, and integral calculus; 2) visual or spatial, such as the number line, Cartesian graph, polar coordinate system, box plots of data, geometrical diagrams, and computer-generated images of fractals; and 3) the words and sentences, written or spoken. Figure " 5 " is an external representation sample that can represent a set consisting of five objects, or may also represent the location or the result of the measurements. Cartesian graphs can describe the data set, or it can represent a function or solution set of algebraic equations. Thus, one thing can represent many things.

According to Goldin (2002), internal representation system consists of several types, which are: 1) verbal-syntactic system, describes the ability of both mathematical and non- 
mathematical natural language and the usage of grammar and syntax; 2) imagistic system, including visual and spatial forms, or "mental images"; 3) formal notation system, the internal configuration associated with conventional mathematical symbol system and the rules for manipulating it. For example, students mentally manipulate numbers, perform arithmetic operations, or visualize the symbolic steps in solving algebraic equations; 4) the system of planning, monitoring and executive controlling or heuristics process and strategy to solve mathematical problems. For example, children develop and manage mental "trial and error" or "working backwards" when solving problems; and 5) the affective system, changes in students' emotions, attitudes, beliefs, and values about mathematics or about themselves in relation to mathematics.

Goldin \& Shteingold (2001) states that someone's internal representation can not be observed directly. However, it can be seen through the students' interaction with their external representation.

\section{Guided Inquiry Learning}

Inquiry learning is a process in which the students are engaged in their learning, formulating questions, investigating widely and then creating understanding, meaning and new knowledge. Through those activities, students will create or construct understanding, meaning and new knowledge. This is in compliance with constructivism theory that all the knowledge we gain is acquired by ourself.

Sund, Trowbridge, and Lieslie (Gani, 2011) divided inquiry learning into three types, according to the magnitude of the intervention or guidance from teachers to students, which are: a) Guided Inquiry: students get guidance from their teacher to understand the concept, then students independently complete the relevant tasks by having discussion or individually; b) Free Inquiry: students are free to determine the problem to be observed, to find and to resolve the problem independently by designing the procedures or steps required with limited or no guidance from their teacher; c) Modified Free Inquiry: collaboration or modification of guided inquiry and free inquiry method. Guidance provided by the teacher to the student is less than that of guided inquiry model and is unstructured. Based on the definition and description of the three types of inquiry methods mentioned above, Guided Inquiry type is allegedly more appropriate to be applied to junior high school students.

The steps of guided inquiry learning used refer to Sanjaya's premise as mentioned by Afgani \& Sutawijaya (2011), which are: 1) Orientation; 2) Formulating problem; 3) Formulating Hypothesis; 4) Collecting data; 5) Testing hypothesis; and 6) Drawing conclusion.

\section{METHOD}

This research conducted by applying quasi experiment method with nonequivalent control group design where the experimental class and the control class were not chosen at random (Sugiyono, 2011). The design is:

$$
\begin{array}{llll}
\mathrm{O}_{1} & \mathrm{X} & \mathrm{O}_{2} & \text { experimental class } \\
\mathrm{O}_{1} & & \mathrm{O}_{2} & \text { control class }
\end{array}
$$

Remarks:

$\mathrm{O}_{1}=$ pretest

$\mathrm{O}_{2}=$ posttest

$\mathrm{X}=$ guided inquiry learning 
The Subjects of the research are students of Dharma Karya UT Middle School at $8^{\text {th }}$ Grade. Selecting for Middle School student as subject conducted according to the following considerations. Middle School students are having $11-16$ years old. According to Piaget, children on these ages already had formal or abstract mind level. This matters are suit with the representation refer to abstraction forming. In addition to that, the implementation of guided inquiry learning is most appropriate to be implemented for Middle School student, considering that Middle School student still need dominantly guidance within session learning.

Selecting for $8^{\text {th }}$ Grade by considering as follow: 1) students at this class have more homogeny within their basic competencies; 2) students at $8^{\text {th }}$ grade have not been undergoing National Examination (UN) so that it wouldn't disrupt their preparation; 3) students at $8^{\text {th }}$ Grade have been more adapted with new school environment (from Elementary up to Middle School) compared with student at $7^{\text {th }}$ Grade. Dharma Karya UT Middle School has four $8^{\text {th }}$ grades. 19 students selected as control grade and 20 students selected as experiment grade.

Research instrument covers: a) ability test of mathematic representation; b) observation sheet; and c) interview guideline. Early step conducted in making instruments are making instrument summary and designing research instrument. All of the instruments was validated by validator.

To analyze Mathematical Representation of students, the Learning tools was developed. The tools developed to facilitate teachers and students in implementing the guided inquiry learning. These tools also used to guide teachers in implementing the learning that can improve the Ability of Mathematical Representation of students. Developed learning tools consist of Learning Implementation Plan (RPP) and the Student Worksheet (LKS). RPP developed to guide teachers for learning implementation according to the steps of guided inquiry learning model, while LKS developed to guide students in conducting learning activities. Prior to use, the learning tools e must first be validated learning. Once validated, revised learning tools based on the input of the validators. Validation conducted by math education expert from University of Bengkulu and Indonesian Education University.

Data in this research comprises of two kinds, are namely qualitative and quantitative data. Qualitative data gained from validation result of expert to research instrument, observation result to teacher and student activities, and interview result of teachers. Qualitative Data analyzed descriptively to backup the completeness of quantitative data and to answer the research questions. Quantitative Data gained through trial result analyzing to view reliability, validity, difficult level and differentiation power for test instrument, along with analysis regarding student respond upon student mathematic representation test.

\section{RESULTS AND DISCUSSION}

\section{Results}

The purpose of this research is to comprehensively analyze differences in increasing of math representation ability (MRA) of students who got a guided inquiry learning and who received conventional learning. Data relates with the pretest, posttest, and N-gain MRA students presented in the following figure. 


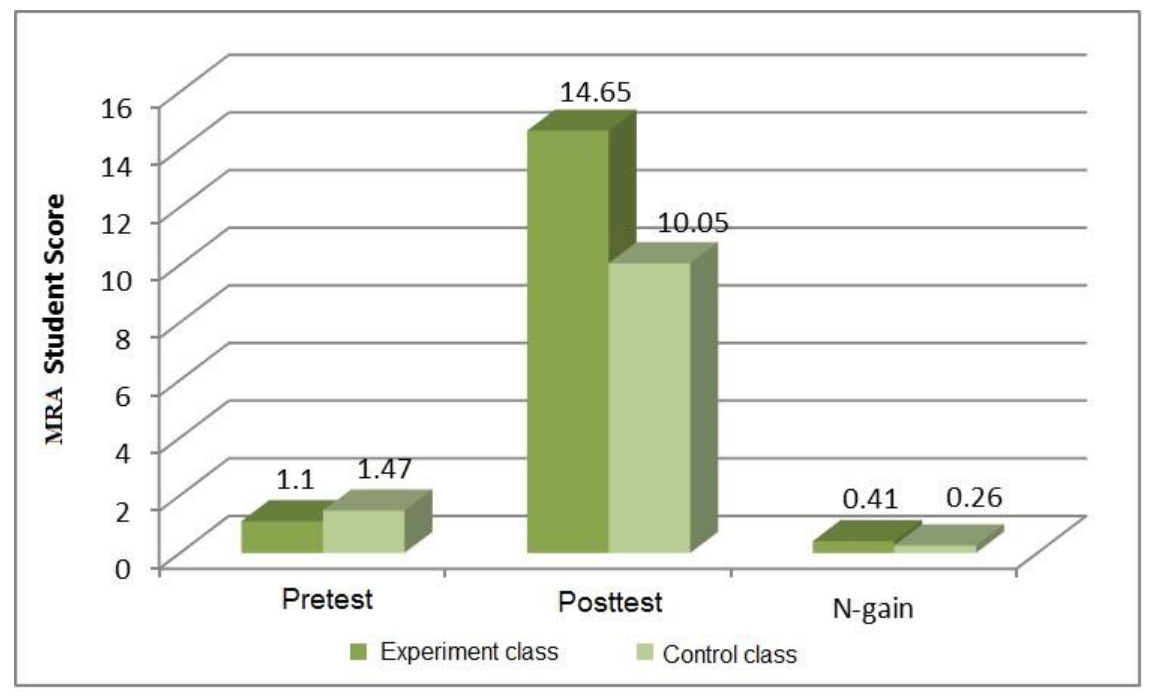

Figure 1. Diagram of MRA Student Data

Based on Figure 1, it indicated that the average pretest students MRA relatively similar between the experiment class students and control class student. However, after learning MRA posttest scores, obtained that experiment class students is higher than the control class. $\mathrm{N}$-gain MRA experiment class student is 0.41 including medium category, while $\mathrm{N}$-gain MRA control class student is 0.26 , which included as low category. Based on 1, achievement and improvement of MRA experiment class students is higher than the control class students.

Trial result of wider model indicates that extensive guided inquiry learning is more effective in achieving and increasing MRA Student than conventional learning. This is indicated by any significant difference between the achievement and improvement MRA between student group of guided inquiry learning with student groups of conventional learning. Achievement and increasing MRA student group of guided inquiry learning group is higher than student group of conventional learning. The magnitude of the increasing in MRA student group of guided inquiry learning group is 0.41 included as medium category.

Based on statistical calculation, the difference increased MRA ability of students in both groups of study obtained the following results.

Table 1. Results of Normality N-gain Data of MRA

\begin{tabular}{lccccc}
\hline \multicolumn{1}{c}{ Data Group } & N & Avarage & Dev. Stand. & Sig. (2-way) & H $_{\mathbf{0}}$ \\
\hline N-gain of Control Group & 19 & 0.26 & 0.119 & 0.612 & Accepted \\
N-gain of Experimental Group & 20 & 0.41 & 0.167 & 0.042 & Rejection \\
\hline
\end{tabular}

Based on Table 1, one of the MRA data is not normally distributed. Therefore, to know the difference between the two groups, namely guided inquiry learning and conventional learning Mann-Whitney test was used.

Different test increasing (N-Gain) math representation's student (MRA) in both groups using the Mann-Whitney Ho generate revenue. This means, by increasing the MRA of students taught using the guided inquiry learning better than students taught using conventional learning. This is shown in Table 2 below. 
Tabel 2. Results of Mann-Whitney Test of MRA

\begin{tabular}{lccccc}
\hline \multicolumn{1}{c}{ Data Group } & Avarage & $\begin{array}{c}\text { U Mann } \\
\text { Whitney }\end{array}$ & $\boldsymbol{Z}$ & $\begin{array}{c}\text { sig. } \\
\text { (2-way) }\end{array}$ & $\mathbf{H}_{\mathbf{0}}$ \\
\hline N-gain of Control Group & 0.26 & 77.000 & -3.218 & 0.001 & Rejection \\
N-gain of Experimental Group & 0.41 & & & \\
\hline
\end{tabular}

In other words, guided inquiry learning effect on increasing the MRA of students. Meanwhile, the increasing MRA student group of conventional learning is 0.26 included as low category. Although the guided inquiry learning is more effective in achieving MRA student, but these achievements is not maximum. Posttest scores obtained by student group of guided inquiry learning group is 14.65 , which still under median of maximum score (17.5), while the posttest scores MRA student group of conventional learning is 10.05 , which still under the score of MRA student group of guided inquiry learning. The research result is consistent with Alhadad (2010) which concludes that improvement the ability of multiple representations of mathematical learning of students who receives open-ended approach is better than the students who receives the usual learning, reviewed from whole students.

Mathematical representation ability as used in this study using indicators as follow. a) To use the symbolic notation, visual or spatial, and words or phrases in solving mathematical problems; and b) To change from one representation form to another one. To provide a clearer description of MRA students, the following given examples of the students' answers and analysis of faults based on MRA indicators.

Test relates with first MRA indicator is namely:

comparison of length, width, and height of a rectangular prism is 5: 1: 2 . If the prism volume is $1,250 \mathrm{~cm} 3$, then defines surface area of a prism!

The following given some student's answer relate with the test.

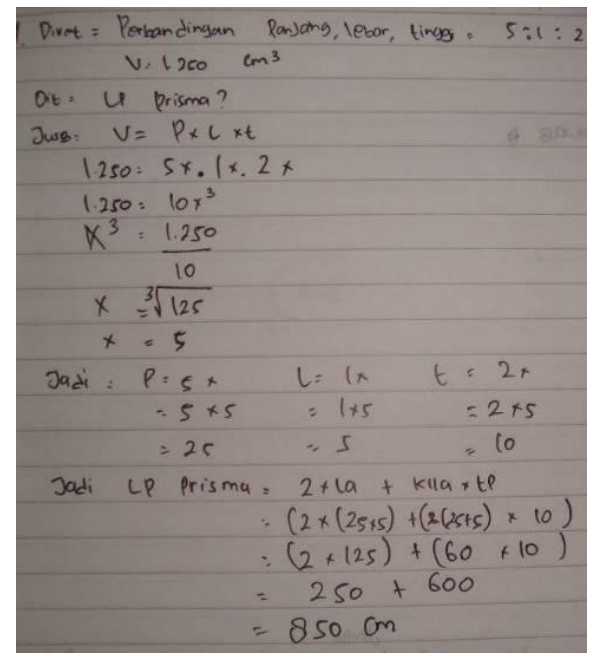

Figure 2. Correct answer sample of MRA Student Indicator 1

This student has understood the symbolic notation used in the test, and able to use these notations in solving the problem. Meanwhile, the following students still have trouble to understand symbolic notations. 


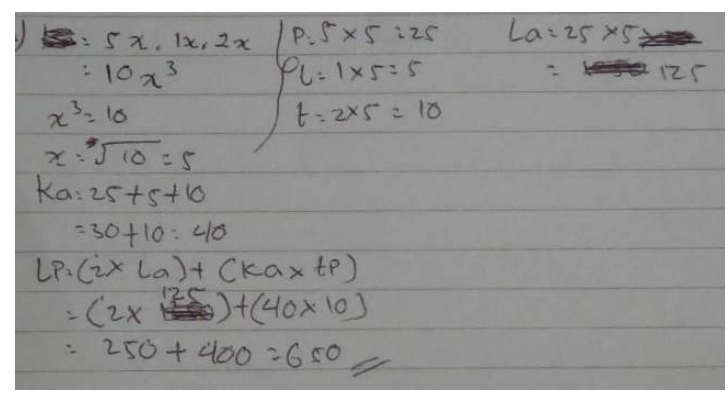

Figure 3. Fault answer sample of MRA Student Indicator 1

Test relates with second MRA indicator is namely:

It known cylinder with radius is $r \mathrm{~cm}$ and height is $\mathrm{cm}$ as shown below. Cone has a radius and a height equal to the cylinder. Determine the ratio between the cone volume and cylinder volume.

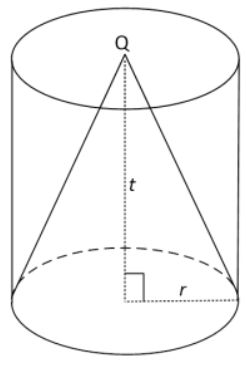

Here are sample of student answers that able to change from image representation to verbal representation.

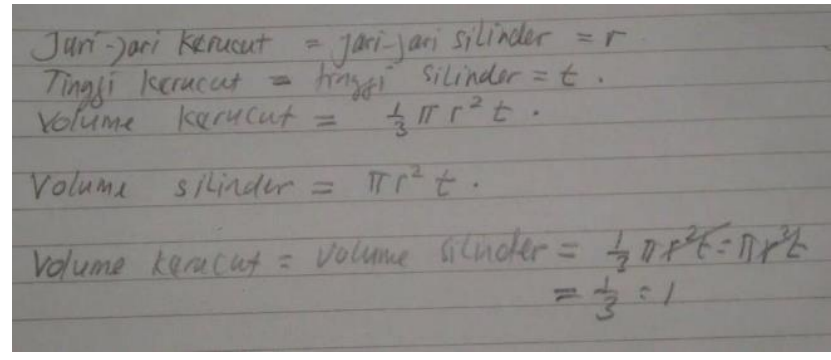

Figure 4. Correct answer sample of MRA Student Indicator 2

Although students have not completed solving the problem, but they have shown their abilities in mathematical representation. Meanwhile, the following students are still weak resentation capability

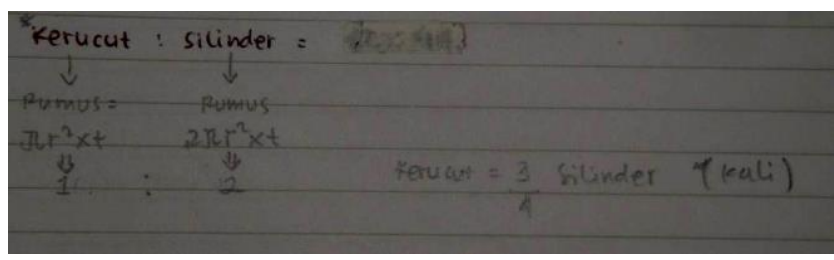

Figure 5. Fault answer sample of MRA Student Indicator 2 


\section{Discussion}

\section{Guided Inquiry Learning Model}

All guided inquiry learning ineffectiveness can be explained through the stages of learning as follows.

\section{First Stage: Orientation}

At this stage, the main activity of learning is the teacher motivates student through the explanation of the topic, objectives, learning outcomes expected to be achieved by students, explanation of the main points of guided inquiry learning activities that must be performed by the students to achieve the goal. At this stage the teacher also performs apperception, which is reminiscent of the material relating to the material will be learned. For example, when it will discuss the topic of the surface area of the prism, the related materials is flat building region area. Through the question and answer, the teacher reminds the area of triangle, rectangle, parallelogram, and so on. This activity relates to the deductive reasoning of students. Thus, activities orientation can make MRA students better.

\section{Second Stage : Problem Formulating}

Problem formulating is a step to bring students to an issue that contains puzzles. For example, when students given the following problem.

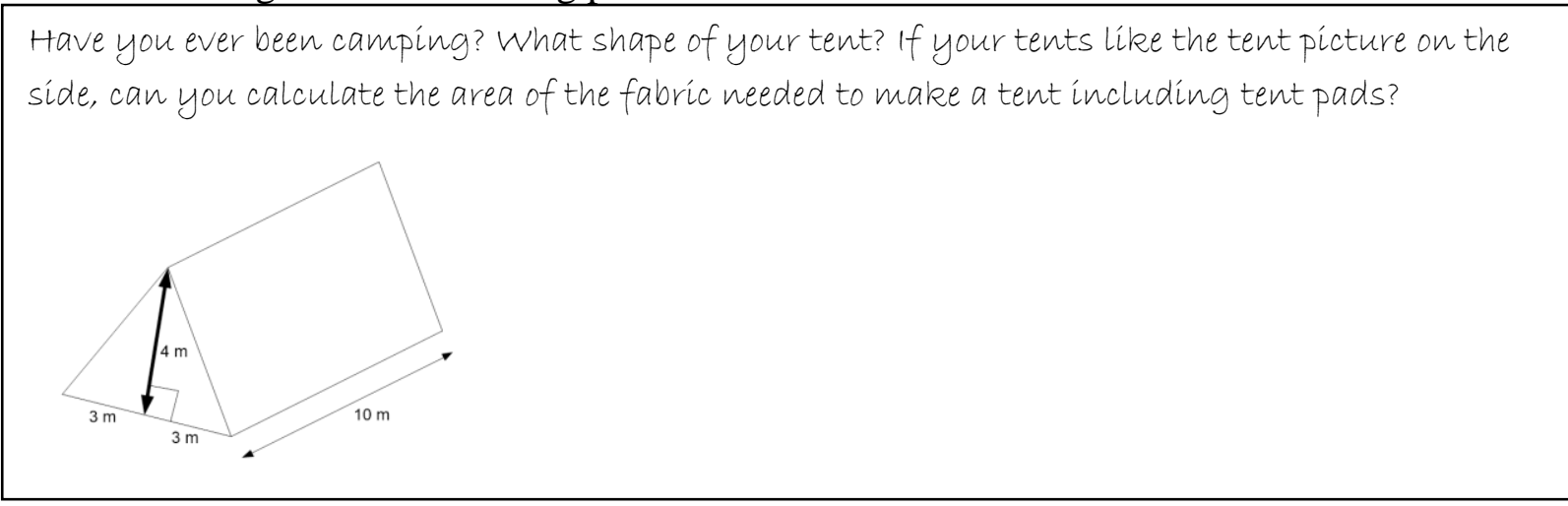

Figure 6. Sample of Problem Formulating

When formulating the problem, students must know what information is contained in matters provided by teacher and what you want to achieve from the settlement of the issue. The information contained in Problem 1 is:

a. Tent is a triangular prism shape.

b. Tent dimension consists of: rib base and height of a triangle which is the prism base, as well as high prism

c. What want to be achieved from Problem 1 is the surface area of the prism

This activity is deductively reasoning, because at here the students put the premises and attempt to draw a conclusion. In formulating the problem, it required to form images, graphics, or verbal statement to clarify the premises. For example, in Problem 1, students must understand the overall shape of a tent image, and image form the sides of the prism. Students also need to understand the numbers shown in the image, which indicate what size. These activities require the ability of the student representation. Thus, the activities to formulate the problem can practice MRA students. 


\section{Third Stage: Hypothesis Formulating}

The hypothesis is temporary answer of a problem being studied. In the reasoning activity, this activity called also composing a conjecture. When composing a conjecture, students observe and analyze whether found a pattern or whether the problem can be generalized. For example, in the completion of Problem 1, students asked to formulate a conjecture about the surface area of the prism through props forms prism made of cardboard. Prisms of the cardboard cut by students based on the corresponding ribs, so that will be formed prism nets. Students observe and analyze the general pattern of the surface area of the prism from prism nets formed. This activity is reasoning inductively. The formulation of this hypothesis can also be done by guessing intuitively, thus this activity is an activity intuitive reasoning. In activities discover patterns or generalize sometimes students do it with the help of images, tables, graphs, or verbal form, so that the representation ability plays a role in this activity. In other words, through this hypothesis formulating, MRA can develop or increase.

Sample of student activities in making prism nets.

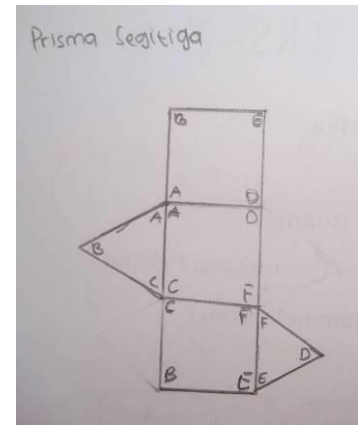

(a)

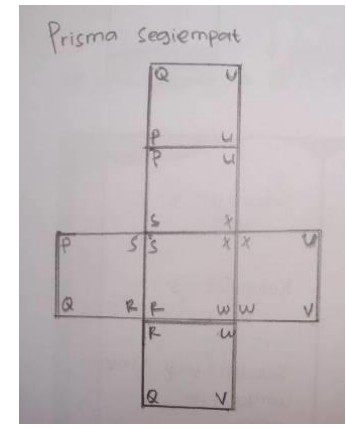

(b)

Figure 7. Sample of prism nets made by students

\section{Fourth Stage: Data Collecting}

Data collecting is activity to capture information needed to test the proposed hypothesis. An activity of collecting data filled with intuitively reasoning activities. Students intuitively collect and arrange data needed to test the conjecture. For example, when completing Issue 1, students have created a conjecture through observation and analysis of prism nets. To test the truth of the conjecture, students search the required data, for example, shape and size of ribs from the sides of the prism. These data can also be a visual form (tables, images, and graphics). In inquiry learning, data collecting is a mental process that is very important in the intellectual development. The data collecting process not only requires a strong motivation to learn, but also requires persistence and the ability to use the potential of thinking.

Examples of student activities Figure 3. for data collect that when students are looking for a hypotenuse of prism base triangle. Hypotenuse is one of the prism ribs.

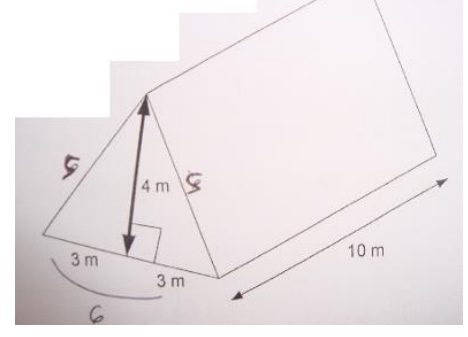


Figure 8. Example of Data Collecting Student activities

\section{Fifth Stage: Hypothesis Testing}

Hypothesis testing is to determine the answer that considered acceptable in accordance with the data or information obtained based on the data collecting. Hypothesis testing also means developing the ability to think rationally. The meaning is the truth of the answers given not only by argument, but must be supported by the data found and accountable. This hypothesis testing must use rules, nature, and existing definition, so that produces a new rule or a trait. This activity filled with activities of deductive reasoning. In testing hypothesis, it often used representation of images, graphs, tables, and verbal forms.

\section{Sixth Stage: Conclusion Formulating}

Conclusion formulating is the process of describing the findings obtained based on the results of hypothesis testing. Rules and nature that have been concluded is then extended to apply to the more complex problems. This latest activity is a deductively reasoning activity. When the conclusions obtained reinforced by applying to the more complex issues, the role of representation is also very important because in the resolution of complex problems need to be presented in the form of pictures, graphs, tables, and verbal forms.

Example of conclusion given to students relates with surface area of the prism as shown below.

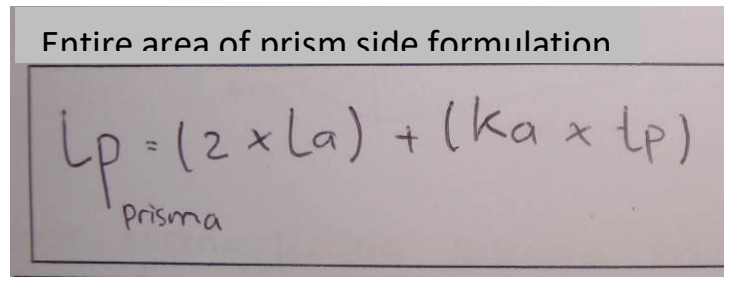

Figure 9. Student conclusion example

Remark:

$\mathrm{L}_{\mathrm{p}}=$ prism surface area

$\mathrm{L}_{\mathrm{a}}=$ pad area

$\mathrm{K}_{\mathrm{a}}=$ pad surrounding

$\mathrm{t}_{\mathrm{p}}=$ prism height

Examples of more complex issues related to the surface area of the prism are namely:

By dividing into several prisms, calculates area surface of these materials
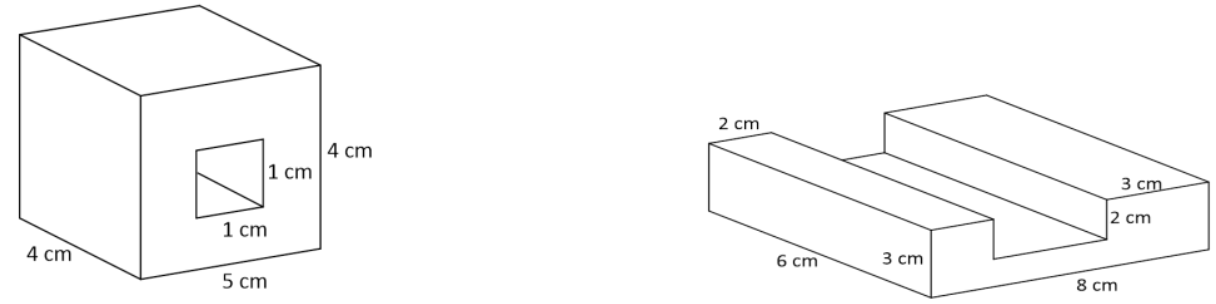

a.

b.

Figure 10. complex issues related to the surface area of the prism 
Thus, the habits conducted by students at each stage in the overall guided inquiry learning can improve students' MRA. These habits if done continuously will contribute to a good impact for the development of students' thinking skills that needed to jump into the community later. In conventional learning, teacher explains all the material and students just listen. Then the teacher gives examples of questions, and students then do the exercises. Meanwhile, the material not given directly at the guided inquiry learning,. Students are actively thinking to discover facts, concepts, and procedures. This is in line with the theorem construction of Bruner (Hudojo, 1988) which states that the best way of thinking for students to begin learning the concepts and principles in mathematics is to construct their own concepts and principles learned.

Thus, students taught through guided inquiry learning, have more deepened understanding of newly learned material than conventional learning. Strong understanding can improve students' MRA. In addition, students taught through guided inquiry learning, have longer memory storing regarding newly learned material than conventional learning. This is in line with Dahar (1988) which states that some of the advantages of learning is the knowledge discovered last long or easier to remember, has an effect of better transfer.

The results of this study will reinforce and complement the findings of related research on inquiry learning, namely research conducted by Gani (2007), and Wardani (2009). Gani (2007) concludes that the inquiry-learning model of Alberta can improve comprehension and problem-solving abilities of high school students. Research conducted by Wardani (2009) found that the inquiry-learning model of Silver can develop creativity and problem solving skills at mathematical high school students.

\section{CONCLUSION}

Mathematical representation is important ability in mathematics. One of the reasons why it is important is because representation refers to abstrack formation and demonstration of mathematical knowledge, as well as illustration of mathematical problem solving situations. The use of different modes of representation and relationship between them illustrates the starting point in mathematics education in which the students use a symbolic system to expand and to understand others, and many other reasons to convince that representation is an ability that must be mastered by students in learning mathematics.

Guided inquiry learning model can be used to improve the ability of mathematical representations. Inquiry learning is a series of learning activities which maximally involve the student's ability to search and investigate the problem systematically, critically, logically, analytically, so that they can formulate their own findings confidently. Allegedly, by applying guided inquiry learning and mathematical representation, the student's math reperesentation skill can be enhanced. It may be caused by the activities in inquiry learning that is filled with reasoning and manipulation from one representation to another representation.

\section{REFERENCES}

Afgani, A. S. J., \& Sutawijaya, A. (2011). Pembelajaran Matematika. Jakarta: Universitas Terbuka.

Alhadad, S. F. (2010). Meningkatkan Kemampuan Representasi Multipel Matematis, Pemecahan Masalah Matematis, dan Self Esteem Siswa SMP melalui Pembelajaran 
dengan Pendekatan Open Ended(Doctoral dissertation, Universitas Pendidikan Indonesia).

Anastasiadou, S. D. (2008). The Role of Representations in Solving Statistical Problems and the Translation Ability of Fifth and Sixth Grade Students. International Journal of Learning, 14(10), 125-132.

Ayalon, M., \& Even, R. (2010). Mathematics Educators' views on the Role of Mathematics Learning in Developing Deductive Reasoning. International Journal of Science and Mathematics Education, 8(6), 1131-1154.

Dahar, R. W. (1988). Teori-teori belajar. Departmen Pendidikan dan Kebudayaan, Direktorat Jenderal Pendidikan Tinggi, Proyek Pengembangan Lembaga Pendidikan Tenaga Kependidikan.

Gani, R. A. (2007). Pengaruh Pembelajaran Metode Inkuiri Model Alberta terhadap Kemampuan Pemahaman dan Pemecahan Masalah Matematika Siswa Sekolah Menengah Atas. (Doctoral dissertation, Universitas Pendidikan Indonesia).

Gani, W. (2011). Pembelajaran Inkuiri. Available at: http://widodoalgani. blogspot. com/2011/09/pembelajaran-inkuiri. html [25 April 2012]..

Goldin, G., \& Shteingold, N. (2001). Systems of Representations and the Development of Mathematical Concepts. The Roles of Representation in School Mathematics, 2001, 1-23.

Goldin, G. A. (2002). Representation in Mathematical Learning and Problem Solving. Handbook of International Research in Mathematics Education, 197-218.

Hudojo, H. (1988). Mengajar belajar matematika. Jakarta: Depdikbud.

Ozyildirim, F., Ipek, S., \& Akkus, O. (2009). Seventh Grade Student's Translational Skills Among Mathematical Representations. International Journal of Learning, 16(3), 197206.

Sugiyono, D. (2011). Metode Penelitian kuantitatif, kualitatif dan kombinasi (Mixed Methodes). Bandung: Alfabeta.

Suryadi, D. (2005). Penggunaan Pendekatan Pembelajaran Tidak Langsung serta Pendekatan Gabungan Langsung dan Tidak Langsung dalam rangka Meningkatkan Kemampuan Berpikir Matematik Tingkat Tinggi Siswa SLTP (Doctoral dissertation, Universitas Pendidikan Indonesia).

Trianto, M. P. (2009). Mendesain Model Pembelajaran Inovatif-Progresif. Jakarta: Kencana.

Wardani, S. (2009). Pembelajaran Inkuiri Model Silver untuk Mengembangkan Kreativitas dan Kemampuan Pemecahan Masalah Matematik Siswa Sekolah Menengah Atas. (Doctoral dissertation, Universitas Pendidikan Indonesia). 